\title{
REHABILITANDO HISTÓRICAMENTE AL PORFIRIATO: UNA DIGRESIÓN NECESARIA ACERCA DEL RÉGIMEN DE PORFIRIO DÍAZ. MÉXICO 1876-1910
}

\section{A HISTORICAL REHABILITATION OF THE PORFIRIATO. A NECESSARY DIGRESSION OF PORFIRIO DIAZ'S REGIME. MEXICO 1876-1910}

\section{Arnaldo Moya Gutiérrez*}

RESUMEN

La Revolución de 1910 puso fin a la era de Díaz y vilipendió su figura al desconocerle como el padre del México moderno. Los ideólogos de la revolución estaban interesados en acreditarle a esta el advenimiento de la modernidad mexicana y de satanizar al régimen de Díaz. Así, sobre el olvido, se construyó la historia del México moderno. En este artículo reivindicamos al Porfiriato como un periodo fundamental de la historia de México.

PALABRAS CLAVE: MÉXICO * ANÁLISIS HISTÓRICO * PORFIRIATO * HISTORIOGRAFÍA * PODER * ÉLITE * CONFRONTAMIENTO POLÍTICO * REVOLUCIÓN

ABSTRACT

The Porfirian Age was a hard time of mexican historiography. The revolution of 1910 ended the time of Porfirio Diaz, and it contempted the dictator figure. The revolutionary ideology was interested in accrediting the modern period of Mexico to the revolution. This article claims that the Porfirian age was a funtamental period of mexican history.

KEY WORDS: MÉXICO * HISTORICAL ANALYSIS * PORFIRIAN AGE * HISTORIOGRAPHY POWER * ELITE * POLITICAL CONFRONTATION * REVOLUTION 


\section{INTRODUCCIÓN}

El Porfiriato fue el periodo histórico en que la nación mexicana fue gobernada, de facto, por Porfirio Díaz entre 1876 y 1910 . Ante un siglo XIX que acusa gran sismicidad política surge la era de Díaz como una época de apaciguamiento $y$ de paz prolongada que no habían conocido los mexicanos desde la revolución de independencia en 1810. La pugna ideológica posterior, entre facciones liberales y conservadoras, las guerras contra las intervenciones extranjeras, la Reforma, los imperios y el triunfo indiscutible de los liberales en 1867 fueron determinantes en la conformación del siglo XIX mexicano. La lucha ideológica y la beligerancia de los partidos en pugna ocupan gran parte de este agitado siglo ${ }^{2}$. Fue debido al enfrentamiento ideológico - pero también a ciertas transacciones políticas - entre las diversas facciones y a raíz de la restauración de la república que los héroes que coronaron el panteón heroico mexicano fueron los de acrisolado linaje liberal y republicano ${ }^{3}$. Se erigieron edificios

$1 \quad$ El gobierno de facto incluye las reformas constitucionales que daban pábulo a la ficción democrática de las reelecciones sin contrincante y ganadas por unanimidad, aunque se pusiera en entredicho la "legitimidad" instaurada por el régimen.

Para un acercamiento a los inicios de la lucha ideológica véase el capítulo titulado "El juego político inicial" en: Reyes Heroles, El liberalismo mexicano Tomo II La sociedad fluctuante. México: Universidad de México. 1958, pp. 47-78. En el capítulo siguiente del mismo tomo, titulado "Las fuerzas en pugna" se consideran los actores colectivos que participan en el proceso histórico del siglo XIX mexicano. $y$ monumentos para conmemorar a la patria $y$ se crearon las tradiciones cívicas republicanas que hasta hoy rigen el calendario cívico. Los principales mitos establecidos conducen a la creación de un panteón heroico liberal forjado en el campo de batalla y decantado de las tensiones políticas y sociales que campearon por doquier a lo largo del siglo XIX. Los héroes liberales adquirieron su pasaporte a la eternidad en los más cruentos debates del congreso $y$ en los discursos cívicos, además, hubieron de ganarle la partida a Iturbide quien lucía como el héroe invicto de los conservadores. La Revolución de 1910 puso fin a la era de Díaz y denostó su figura hasta el punto de desconocerle como el padre del México moderno. Los ideólogos de la Revolución estaban interesados en acreditar a esta el advenimiento de la modernidad en todas las estructuras, incluso en las de carácter cultural.

El Porfiriato ha sido caracterizado por distintos autores como un régimen personalista, autoritario y sumamente complejo por cuanto los gobernados parecían aceptar, en principio, la renuncia a las libertades civiles en aras de la paz y la seguridad. La literatura histórica surgida tras la revolución negaba a dicho periodo cualquier intento de modernización porque ese proceso cabía sólo a la Revolución de 1910 y no al Antiguo Régimen. Cosío Villegas en su ingente estudio sobre el Porfiriato se apresura a desautorizar este argumento ${ }^{4}$.

El propósito de este artículo es hurgar en diversas fuentes la rehabilitación histórica del Porfiriato y redimensionarlo como un periodo fundamental de la historia moderna de México.

\section{EL RÉGIMEN Y LA CIUDAD DE MÉXICO}

Como centro del poder político y administrativo, la ciudad de México fue la ciudad

y formación de las naciones. Perspectivas históricas de América Latina. México: Fondo de Cultura Económica. 1999, p. 14.

4 Cosío Villegas. Llamadas. México: El Colegio de México. 1980. Es esta una compilación de las introducciones generales y particulares de la Historia Moderna de México. El prólogo es de Charles Hale. 
porfiriana por antonomasia. Así, descubrimos una voluntad de transformación del espacio urbano que emanaba de la autoridad central del Estado. La ciudad de México fue seducida por la modernización y se reconoció a sí misma en una arquitectura de carácter público y privado de proporciones monumentales. Las transformaciones arquitectónicas estuvieron sujetas a una determinada interpretación del poder que consideramos como la suma de los procesos históricos, culturales, económicos, sociales y políticos que confluyen en el centro neurálgico de la vida nacional. La ciudad de México ofrece el principal referente espacial del Porfiriato $y$ pudo ser interrogada respecto a sus usos arquitectónicos, pero también fue el lugar de la política y de las luchas simbólicas. La ciudad porfiriana respondería, en este sentido, a los mitos republicanos y a la constitución de un panteón heroico, a los ritos y a las ceremonias de la patria. De este modo la ciudad devino en un espacio/escenario de los grandes momentos de la historia. La ciudad porfiriana debió cumplir una función pedagógica por cuanto desarrolla, paso a paso, un programa oficial de transformaciones sujeto a los propósitos que se le atribuyen a una historia integradora de la nación. Es indiscutible el efecto didáctico y político que implicaban dichas transformaciones supeditadas al ascenso del liberalismo. Esta afirmación nos conduce a valorar el imaginario colectivo -inscrito en la larga duración- de los distintos grupos sociales y a reconocer que la nación recién integrada se proyectaba a través de los mitos $y$ de los héroes de la tradición liberal surgida de la genealogía dictada por ese evangelio secular. El legado arquitectónico del Porfiriato traduce los hitos históricos más destacados del liberalismo al lenguaje artístico y se identifica con las nociones de poder $y$ supremacía. Las obras materiales del régimen sólo aflorarán una vez que la nación ha sido sometida a la pacificación; sin la instauración de la paz difícil hubiera sido alcanzar "el orden $y$ el progreso" que apuntalaron la estructura más sólida del régimen. En la ciudad de México quedó impresa, para la posteridad, la huella del régimen de Díaz. Las compañías fraccionadoras y las compañías constructoras, así como el remozamiento de los distintos medios y vías de transporte, hicieron del paisaje urbano un tributo a la modernidad. El epítome de esta modernidad se ubicó en la ciudad de México y cristalizó en los festejos del primer centenario de la Independencia de México, en septiembre de $1910^{5}$.

\section{LA "PAZ PORFIRIANA"}

El Porfiriato estuvo precedido por toda suerte de convulsiones políticas. Una de las más graves consecuencias de la descomposición política y social que siguió a la Independencia "fue una larga crisis de hegemonía, es decir que ningún grupo lograba imperar: era posible derrocar a un gobierno y establecer otro en su lugar, pero imposible hacerlo duradero pues no tardaba a su

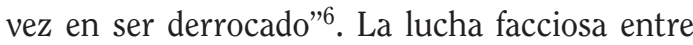
los distintos grupos se llevó al plano ideológico y en especial, al campo de batalla ${ }^{7}$. La pugna ideológica postergó la paz hasta el "triunfo grande" de los liberales en 1867.

El establecimiento del la "paz" política fue considerado como el requisito esencial para la construcción de la nación y para el desarrollo económico, justificando así la imposición autoritaria del orden en nombre del progreso como un medio necesario ${ }^{8}$. En nombre de la paz se sacrificó a la nación política y a la organización partidista, aunque eventualmente se conformaría una oposición organizada cuyo sino fue liderar la Revolución de 1910. Históricamente el Porfiriato se vio precedido por una época sumamente convulsa donde las gavillas, los pronunciamientos y levantamientos — heredados de

\footnotetext{
$5 \quad$ Véase en: García. Crónica..., 1991.

6 Ortiz Monasterio. México eternamente..., 2004, p. 255.

$7 \quad$ Fue extirpando los odios acumulados a raíz de la guerra de Independencia, de la invasión norteamericana, de la intervención y del Segundo Imperio que cobran un significado especial términos tales como pacificación, consenso y conciliación.
}

8 Garner. Porfirio Díaz. Del héroe al dictador. México: Editorial Planeta, 2003, p. 165. 
la revolución de Independencia- estaban a la orden del día ${ }^{9}$. Díaz logró la profesionalización del ejército y la lealtad de los oficiales. En el ámbito electoral, los gobernadores y los jefes políticos, los puestos elegibles y los no elegibles, debieron gozar del beneplácito de Díaz. Este tramado de sociabilidades tradicionales no fue roto ni con el triunfo revolucionario ${ }^{10}$.

El apaciguamiento, el clima apropiado para la inversión extranjera, la búsqueda de legitimidad, el desarrollo de las comunicaciones y el progreso en los campos de la cultura $y$ las artes conformaban la agenda más apremiante del régimen. Dicha agenda se proponía modernizar al Estado y develar las imágenes sustanciales del progreso y del éxito en el último tercio del régimen. Fue para entonces $y$, en especial, después de 1900 que el principal objeto

9 Lynch argumentaba "que [a raíz de la guerra de Independencia] Latinoamérica se convirtió en el prístino hogar de los golpes y los caudillos", en: Lynch, Las revoluciones hispanoamericanas..., 1983, p. 383. Guerra también llamó la atención al respecto al explicar las nuevas pautas de sociabilidad que se abrían paso con las revoluciones hispánicas. El problema más apremiante es el de construir un régimen político estable. Los pronunciamientos, los golpes de estado o los levantamientos desempeñan en estos sistemas políticos el papel que las elecciones no pueden desempeñar: el cambio de los gobiernos. En: Guerra, Modernidad $e$ independencia. Ensayos sobre las revoluciones hispánicas. México: Fondo de Cultura Económica. 2001, p. 53. Annino señala que fue con el Plan de Veracruz que intentaba poner fin al Imperio de Iturbide que aparece en escena la práctica del levantamiento. Desde siempre considerado un fenómeno degenerativo ligado a las ambiciones de los generales, el levantamiento fue en realidad la expresión bastante coherente de la compleja relación entre liberalismo y contractualismo que se había instaurado en México en los años de la crisis del imperio. Lo prueba el alto grado de legitimidad que esta práctica conservó en la mentalidad colectiva $y$ de formalización institucional de sus procedimientos.

Annino, "Ciudadanía "versus" gobernabilidad republicana en México. Los orígenes de un dilema". En: Sabato, (Coord.,) 1999, p. 78.

10 El film titulado La ley de Herodes describe con agudeza el problema que hemos enunciado para épocas posteriores al Porfiriato. se trasladó a la edificación de obras públicas $y$ monumentos, de obras de saneamiento y de urbanización cuyo fin último era demostrar que México era una "nación al fin civilizada" ante propios $y$ extraños ${ }^{11}$. Fue esta una labor titánica emprendida por la elite porfiriana al hacer coincidir al devenir histórico de la nación con un estilo arquitectónico que glorificaba y legitimaba a la república liberal. Este expediente se utilizó con suma eficacia en la ciudad capital. El desarrollo material de la capital no fue fortuito, pues procuraba establecer un principio de legitimidad consensual fundado en el apoyo de amplios sectores de la población al régimen que a través de dos elecciones y seis reelecciones se perpetuaría en el poder $^{12}$. Lo que acontecía en la ciudad capital era seguido de cerca por la provincia.

La legitimidad de los gobiernos porfiristas trasciende al ámbito político-electoral. La paz recién instaurada era por todos deseada $y$ es juzgada como el gran logro de Porfirio Díaz. En la "conciliación nacional" jugaron un papel determinante las cuotas de poder concedidas a los hombres fuertes de la capital y de los distintos estados. Son vínculos primarios fortalecidos por quienes se aferran a la estructura del poder $^{13}$. Los vínculos y las redes son de antigua

11 Francisco I. Madero hacía derivar la dictadura de Díaz del militarismo, aunque reconocía que "esta dictadura restableció el orden y cimentó la paz, lo cual ha permitido que llegue libremente a nuestro país la gran oleada de progreso material que invade al mundo civilizado desde mediados del siglo último"; en: Madero. La sucesión presidencial. Según Rabasa lo que hizo "entrar a México en el número de las naciones cultas fueron la seguridad política y la solvencia honorable". Rabasa. La evolución..., 1920, p. 151. Lo que no pueden obviar los detractores del Porfiriato es que sin la paz asegurada y sin el erario público saneado hubiera sido imposible emprender cualquier programa de transformación urbana y de edificación de obras públicas.

12 Rabasa. La evolución..., 1920, p.129. Según Rabasa no fue sino hasta el segundo periodo de Díaz (18841888) en que se constituyó el gobierno plenamente personal de Díaz.

13 Estas circunstancias se dieron al inaugurarse el régimen, pero poco a poco y según lo afirma 
prosapia y se fraguaron a partir de las sociabilidades tradicionales erigidas sobre un sustrato autoritario que, en algunos casos, se remontaba a la antigua autoridad del virrey ${ }^{14}$.

En el Porfiriato el gobierno se esfuerza por mostrar resultados concretos, pues de estos depende el triunfo de su legitimidad. Los resultados más notables, como ya vimos, fueron la instauración de la paz, del orden y del progreso y la creación de un espacio apropiado para la inversión extranjera ${ }^{15}$. Estos resultados son inherentes a la labor de modernización del Estado emprendida por la elite porfiriana. El "progreso" abarca todos los ámbitos; desde la banca hasta las comunicaciones, la salubridad y el avance médico, las artes y la literatura, pero quizá el avance más significativo, el que se percibía a simple vista lo ofrecían las obras públicas y el desarrollo urbanístico ${ }^{16}$. México se mostraba como una vitrina de cara a

Rabasa: "el general Díaz quitó a los gobernadores toda autoridad, asumiendo así toda la responsabilidad; determinó por sí la sucesión de los gobiernos locales, ordenó la elección de todos los representantes". Rabasa. La evolución..., 1920, p.129.

Al respecto véase: Coastworth. "Los orígenes del autoritarismo...". 1975. Lynch. Las revoluciones..., 1983, y Guerra, México: Del Antiguo Régimen..., Tomo I, 1988, pp. 32 y 57.

El saneamiento de las finanzas de la hacienda pública no le es consustancial a todo el Porfiriato, fue con la llegada de Limantour a la Secretaría de Hacienda que se supera el déficit que se arrastra desde la época de la Independencia. No es sino hasta 1895 que las cuentas del Estado se saldaron con un excedente de más de un millón de pesos. Al demostrar la solvencia de la hacienda pública los créditos internacionales no se hicieron esperar; véase: Rabasa. La evolución..., 1920, p. 149 y 151.

16 El famoso gran canal de desagüe del valle de México, las terminales portuarias, el saneamiento de Veracruz, Coatzcoalcos y Salina Cruz fueron obra de S. Pearson, el contratista de don Porfirio. El Sr. Pearson pasó de contratista a inversionista $y$ después de permanecer dos décadas en México se le acusaría de haber sacado más del país que cualquier hombre después de Cortés. Connolly. El contratista..., 1997, pp. 11-12. la modernidad. En este contexto adquieren un sentido particular la participación de México en las exposiciones mundiales y la celebración del centenario de la Independencia, así como la inauguración de obras públicas y monumentos de gran envergadura en la capital y en la provincia. La inauguración del desagüe del Valle de México, en 1900, fue el detonante de esta situación por cuanto

... la ciudad hizo su transformación rápida, guardó su bello aspecto en la parte antigua, y se extendió al occidente en amplia área cubierta de residencias de elegancia moderna y llenas de arte [...] Soberbios edificios públicos, ostentación del arte arquitectónico más elegante, se erigieron: la casa de Correos, el palacio de la Secretaría de Comunicaciones, el Palacio Municipal, lucirían en las mejores capitales europeas; el Teatro Nacional (aún no concluido) podría parearse con los más bellos de Europa; el Palacio del Poder Legislativo, es tan bello como adecuado, y el gran edificio que para sustituirlo comenzó a construirse iba a ser el monumento más grandioso de la ciudad. El Hospital General y la Penitenciaría no tienen rivales en el Continente, por su acomodación y condiciones especiales; el Manicomio, las escuelas normales para varones y para mujeres, el Hospicio de Niños, son modelos en su género, $y$ construcciones de gran costo ${ }^{17}$.

La transformación material del país, en especial de la capital, era el efecto visible de la combinación de tres elementos fundamentales: la paz, el crédito internacional y la mirada que algunos porfirianos eminentes lanzaban hacia el exterior. Estos elementos alcanzaron a conjugarse con la obra de artistas, pensionistas, arquitectos e ingenieros y con la bonanza de compañías constructoras -epítomes del capitalismo- que capturaron la esencia 
de las propuestas urbano-arquitectónicas ${ }^{18}$. El desarrollo arquitectónico del Porfiriato es consustancial y se constituye en el remanente del desarrollo historiográfico de la segunda mitad del siglo XIX. Las obras cumbres de la historiografía mexicana de la segunda mitad del siglo XIX fueron las dirigidas por Vicente Riva Palacio: el México a través de los siglos y por Justo Sierra: México: su evolución política. Ambas obras constituyen los pilares capitales sobre los que se erige la propuesta arquitectónica del régimen de Díaz. Si el objeto de la historiografía liberal era edificar, sobre un pasado reciente, su propia versión de la historia, con la arquitectura del Porfiriato sucede algo semejante. Los escritos históricos magnifican las epopeyas liberales y las materializan en monumentos o en edificios públicos que funcionan como lecciones de cívica para engrandecer a la nación y para enardecer al ciudadano. La arquitectura que referimos expresa mejor que ninguno otro el lenguaje del poder. Considérese también el acervo artístico liberal-republicano constituido por esculturas y pinturas que figuran como el complemento idóneo de la arquitectura porfiriana. La exaltación de las artes transitó desde el taller del linotipo hasta su representación en mármol, bronce, granito y óleo. El culto a la versión liberal de la historia se plasmó en el Paseo de la Reforma, en el Presidio de Lecumberri, en el Manicomio Modelo de la Castañeda, en el Palacio Legislativo Federal y en el Panteón Nacional, en el monumento a la Independencia, el monumento a Juárez, el Palacio de Correos y el de Comunicaciones. Fueron obras públicas que mostraron un perfil del régimen —el más permanente quizáspor cuanto los monumentos que se inaugurarían con ocasión de la celebración del primer centenario de la Independencia de México, en 1910, aun figuran como testigos de época,

18 Para la labor artística de nacionales y extranjeros, así como de los pensionistas se puede consultar: Rodríguez Prampolini. La crítica de arte..., 1997, y para lo relativo a las compañías constructoras, fraccionadoras y deslindadoras, véase: Gortari Rabiela. Memoria y encuentros..., Tomo II, 1988. revalidando y rehabilitando al periodo histórico que celebró su ejecución. En la iconografía que exponen $y$ en las representaciones que ostentan encontramos vertidos los contenidos históricos que cuidadosamente habían sido seleccionados $\mathrm{u}$ omitidos por los intelectuales liberales. El advenimiento de la "paz porfiriana" debe entenderse en un contexto más amplio y contrasta con todos los periodos anteriores por cuanto la época de la paz sobrepone a las evoluciones violentas. La historiografía sobre el periodo también revela esta situación.

\section{LA APOLOGÍA DEL PORFIRIATO EN LA HISTORIOGRAFÍA SOBRE EL PERIODO}

Para comprender la versión depurada $y$ oficial de la historia que emanaba de la pluma de los liberales reparamos en algunas características del régimen de Díaz. Los argumentos esgrimidos por algunos de los más talentosos intelectuales de la época confirman el autoritarismo del régimen como la única vía para el consenso y la paz social. Justo Sierra, en su primera época, estuvo convencido de que el régimen de Díaz debía imponerse con su personalismo y autoritarismo porque

La clase indígena será un obstáculo perpetuo a la normalización de la democracia, porque sus tendencias hereditarias $y$ sus tradiciones la condenan a vivir bajo un régimen oligárquico y patriarcal a un tiempo, único medio político que les permite vivir en paz, único que existe bajo el disfraz de los principios constitucionales $y$ liberales ${ }^{19}$.

Sierra ofrece una versión aséptica de la toma del poder por Díaz y legitima sus constantes reelecciones. Al omitir la disidencia política de algunos actores sociales el régimen se presenta ayuno de contradicciones. La legitimidad del gobernante habría de buscarse en la "voluntad nacional" y no en las urnas, no 
obstante, dicha voluntad no coincide con la más rudimentaria de las prácticas democráticas electorales, ni pretéritas, ni contemporáneas. El juego político está en manos de los amigos del caudillo; es aquí donde el valor de las fidelidades $y$ del compromiso adquiere su mayor significado.

Sierra unge al Presidente Díaz al asegurar

[que] comenzó la nueva administración del general Díaz, desde entonces indefinidamente refrendada, más que por el voto, por la voluntad nacional [...] la opinión imponía el poder al presidente Díaz como quien exige el cumplimiento de un deber, como una responsabilidad que se hacía efectiva $^{20}$.

El espacio para la crítica al régimen en la época de Díaz era, de algún modo, restringido, aunque algunos directores de diarios importantes fueron sometidos al arbitrio de la autoridad suprema y fueron encarcelados como "presos de conciencia" o bien, desterrados. El destierro fue el expediente que se impuso a aquellos allegados, o no, a la figura del dictador que se tornaban incómodos o que empezaban a aglutinar cierto poder local y que a la postre rivalizarían con Díaz. El caso más sonado fue el de Vicente Riva Palacio, quién podría convertirse en un virtual candidato a la presidencia de la República. Ante tal amenaza el gobierno de Díaz lo envió como embajador plenipotenciario ante España, Francia y Portugal. Tales prácticas $y$ algunas más sangrientas como la represión sufrida por los indios yaqui y el asesinato de García de la Cadena contribuyeron a la "leyenda negra" del Porfiriato; aunque como lo ha señalado Guerra, ante el monopolio del poder y de la fuerza el régimen de Díaz actuó con cierta mesura ${ }^{21}$. Dicha mesura habría de precisarse, toda vez que el régimen dictatorial actuó con mano de hierro ante la disidencia.

\footnotetext{
20 Sierra. Obras Completas. Tomo XII, 1957, p. 391

21 Guerra. México: Del Antiguo Régimen..., Tomo I, 1988, pp. 21-22
}

Algunos escritos de Justo Sierra son un claro ejemplo del interés que prevalecía por presentar al caudillo como el dispensador de justicia y de paz y como el árbitro inapelable en toda suerte de asuntos. Sus virtudes personales se confunden con las virtudes como gobernante supremo y en los panegíricos empezó a fraguarse el mito del héroe y el del "necesariato", el mito del varón legal cuyo poder emanaba del "asentimiento general", más que de las urnas;

... En su activo contaba la nueva administración con los grandes ferrocarriles hechos y con el nombre del general Díaz. Pero para que el presidente pudiera llevar a cabo la gran tarea que se imponía, necesitaba una máxima suma de autoridad entre las manos, no solo de autoridad legal, sino de autoridad política que le permitiera asumir la dirección efectiva de los cuerpos políticos: cámaras legisladoras y gobiernos de los Estados; de autoridad social, constituyéndose en supremo juez de paz de la sociedad mexicana con el asentimiento general, ese que no se ordena, sino que sólo puede fluir de la fe de todos en la rectitud arbitral del ciudadano a quien se confía la facultad de dirimir los conflictos [...] Sin violar, pues, una sola fórmula legal, el presidente Díaz ha sido investido, por la voluntad de sus conciudadanos y por el aplauso de los extraños, de una magistratura vitalicia de hecho; hasta hoy por un conjunto de circunstancias no ha sido posible a él mismo poner en planta su programa de transición entre un estado de cosas y otro que sea su continuación en cierto orden de hechos. Esta investidura, la sumisión del pueblo en todos los órganos oficiales, de la sociedad en todos los elementos vivos, a la voluntad del Presidente, puede bautizársele con el nombre de dictadura social, de cesarismo espontáneo, de lo que se quiera; la verdad es que tiene caracteres singulares que no permiten clasificarla lógicamente en las formas clásicas del despotismo. Es un gobierno personal que amplía, defiende 
$y$ robustece al gobierno legal [...] si el gobierno nuestro es eminentemente autoritario, no puede, a riesgo de perecer, dejar de ser constitucional, y se ha atribuido a un hombre, no sólo para realizar la paz y dirigir la transformación económica, sino para ponerlo en condiciones de neutralizar los despotismos de los otros poderes, extinguir los cacicazgos y desarmar las tiranías locales ${ }^{22}$.

Fue merced a la legitimidad forzada y a expensas del sacrificio de la vida política que se lograría "el progreso nacional y la inanición de los grupos políticos" 23 . El "necesariato", la figura del "cesarismo espontáneo" y el "gobierno personal y autoritario", que más tarde será retomado por Daniel Cosío Villegas en la Historia moderna de México, adquirieron un alto grado de difusión y aceptación en la época de Justo Sierra. Con Rabasa fue también un argumento de peso por cuanto

... se decía entonces [durante el Porfiriato], y más se ha dicho después, que el pueblo estaba enervado $y$ envilecido, afeminado por el bienestar que la dictadura le ofrecía a cambio de sumisión. Esta es una vulgaridad como hay muchas, que dichas de ligero, parecieron la primera vez verdades nuevas $y$ trascendentes, $y$ que a fuerza de repetidas pasaron a evangelios indiscutibles $[. . .]^{24}$.

Sierra se convirtió en el "sumo sacerdote" del régimen, toda vez que sus argumentos $y$ réplicas gozaban de gran autoridad entre la gente letrada y la población en general. Estas características unidas a un modo particular de exaltar a Díaz, en el México: su evolución social, condujeron inevitablemente a mirar al Porfiato como a la más venturosa de todas

Sierra. Obras Completas. Tomo XII, 1957, pp. 393 y ss.

23 Sierra. Obras Completas. Tomo XI, Evolución politica, 1957, p. 48. las épocas históricas. Tan elogiado fue el Díaz de Sierra como denostado por los ideólogos de la Revolución. No encontramos matices ni términos medios. La revolución defenestra al Porfiriato y no le concede ningún crédito en cuanto a la modernización de México. El régimen es visto como un periodo oscuro y corrupto que sólo preparó el triunfo revolucionario. Ante el reduccionismo imperante que emanaba del dogma revolucionario se elevaron las voces de intelectuales connotados del Porfiriato. Este fue el caso de Emilio Rabasa. Dicho autor fue contemporáneo a Sierra y dedicó una de sus obras al desarrollo histórico de México: La evolución histórica de México sale a la luz en 1920, pero esta situación no amedrentó los juicios emitidos por este intelectual al esbozar un perfil de Porfirio Díaz y del Porfiriato que iba a contrapelo con los dogmas revolucionarios. En la semblanza de Díaz se revela con penetrante agudeza la percepción que del "dictador" tenía y por ende, de la "dictadura necesaria":

El general Díaz tenía reputación de honradez acrisolada; pero no se veía en él sino al hombre rudo, de ineptitud notoria para el gobierno, falto de instrucción y aun de finos modales [...] La opinión sensata vio pocos años después que se había equivocado en todo, salvo en atribuir al hombre nuevo una honradez personal sin tacha [...] Con el instinto político parecía sustituir los análisis complicados [...] Tenía la ambición de llegar al poder absoluto, sea por convicción o por egoísmo, sabía que eso no se alcanza por la fuerza, sino por la habilidad mañosa, mezclada de energía oportuna $y$ violenta, pero excepcional, que ha caracterizado a los grandes dictadores [...] Para hacer un gobierno nacional, debía acabar con las divisiones internas; debían desaparecer las fracciones, fundidas todas en la adhesión común a la persona del Presidente [...] Al cabo de un tiempo, la unión estaba en la persona del general Díaz, de cuya mano pendía la posición de cada individuo, y en cuya voluntad estaban todas las voluntades 
[...] y sea porque no pudiera evitarlo o porque creyera conveniente a su política ostentar su poder absoluto, se exhibió como el depositario único de la autoridad de la nación ${ }^{25}$.

El gobierno de Díaz calificado por Rabasa como una "dictadura de hecho", pero "cuidadosa de las formas constitucionales [...] no entra en la clasificación de las tiranías, ni el general Díaz en la lista de los déspotas" ${ }^{26}$. De la tercera reelección dice Rabasa que:

El Presidente fue reelecto como antes, por el sistema mecánico oficial que servía para todos los actos electorales. La opinión pública que lo sostenía de buen grado en su obra de regeneración nacional, que lo ensalzaba con cariño y lo aplaudía con entusiasmo, no iba a las urnas electorales; celebraba que el general Díaz continuara en la Presidencia, pero censuraba la forma de la elección" 27 . [Más adelante, apunta Rabasa, que la elección de 1888] ... determinó el establecimiento del gobierno absolutamente personal, la de 1892 dejó en la conciencia pública la convicción del gobierno perpetuo; pero este era tan fecundo y tan fuerte, que nadie quería ni creía posible una rebelión armada, aunque sí se pretendía mejorar la condición política ${ }^{28}$.

Estas mejoras se limitaban a asegurar la independencia de la justicia y crear la vicepresidencia de la república para asegurar la sucesión presidencial. En la quinta, sexta y sétima reelección presidencial, con el mecanismo reelectivo constitucional idóneo no había que legitimar el ascenso del mismo personaje al solio presidencial una vez más. "La dictadura

Rabasa. La evolución..., 1920, pp. 105-129. El destacado es nuestro.

Rabasa. La evolución..., 1920, p. 130.

Rabasa. La evolución..., 1920, p. 139.
- señala Rabasa- contó ampliamente con la opinión pública durante muchos años. El pueblo prefería la seguridad exterior e interior a las discusiones de la libertad que tan caras habían costado a la nación y a las familias [...] La opinión pública facilitó la suavidad de la dictadura y colaboró con esta, inconcientemente la opinión alentaba al régimen y lo ayudaba a arraigarse $y$ a perpetuarse" 29 . Pero eso que califica Rabasa como opinión pública ¿por quiénes estaba constituida? La restricción de las libertades públicas estaba en franca relación ya no sólo con quienes si tenían derecho de emitir su opinión -favorable al gobierno las más de las veces - sino con aquellos, que como es el caso de Rabasa, legitimaban al establishment.

El juicio esclarecido de Cosío Villegas es el responsable de la "rehabilitación histórica" del Porfiriato en la obra capital por él dirigida: Historia moderna de México (1956-1972). En su opinión el régimen de Díaz había procurado recoger

... todos los matices de los grupos políticos de entonces: católicos, conservadores, liberales puros y moderados, juaristas, porfiristas, lerdistas o iglesistas. El régimen de Porfirio Díaz quiso nutrirse, desde su segunda gestión presidencial, de un amplio espectro de facciones políticas que apuntaba a la conciliación nacional ${ }^{30}$.

En medio de concepciones históricas adversas al Porfiriato, que impedían su revisionismo y tras largos años de investigación, Cosío Villegas aquilató el periodo y abrió nuevos

Los argumentos de Rabasa para legitimar a la dictadura y subestimar a la opinión pública merecen un análisis que considere los factores previos al estallido revolucionario; Rabasa. La evolución..., 1920, p. 186 y ss.

30 Rabasa. La evolución..., 1920, p. 124 y 128. Según Rabasa, al nombrar en el segundo gobierno de Díaz a elementos del lerdismo y, aún, del Segundo Imperio, se daba un paso muy importante en esta reconciliación; véase un argumento semejante en: Cosío Villegas. Llamadas, 1980, p. 11. 
espacios a los estudiosos mexicanos y extranjeros. Hale ha señalado que

[...] Cosío Villegas nos ofrece, por vez primera, una comprensión pormenorizada y una valoración juiciosa de la política porfiriana. Su mayor logro es haber roto la barrera ideológica de 1910, haber renunciado a la perspectiva revolucionaria vulgar, que considera al Porfiriato únicamente como un "Antiguo Régimen" opresor $^{31}$.

Hale hace eco de la crítica al reduccionismo imperante tras el triunfo de la revolución de 1910, por cuanto señala que: "frente a la ortodoxia revolucionaria Cosío Villegas presenta como desarrollo una era que anteriormente había sido interpretada tan sólo como una totalidad monolítica y -en una polémica con los teóricos de la revolución mexicana - afirma "que el régimen de Díaz puso las bases de una moderna economía nacional"32. Según Cosío Villegas

... el rasgo más sobresaliente del Porfiriato es una filosofía política en que priva como meta principal e incluso única, el crecimiento económico, con las dos fallas que semejante filosofía trae consigo de un modo casi inevitable: por una parte, el descuido o el sacrificio de las libertades públicas, que acaba por producir el descontento, la irritación y finalmente la rebeldía; por otra parte, la desigual repartición de la nueva riqueza generada por el progreso económico ${ }^{33}$.

Algunos años después y con un arsenal impresionante de fuentes Guerra apuntaló los argumentos en pro del Porfiriato que Cosío Villegas había esbozado. Según Guerra los mecanismos de conciliación y el reforzamiento de antiguas redes $y$ vínculos son en última

1 Cosío Villegas. Llamadas, 1980, p. 11.

Cosío Villegas. Llamadas, 1980, p. 13. instancia los responsables de las condiciones políticas y de las características que impregnaron al Porfiriato. Las sociabilidades modernas están permeabilizadas por la política y por formas sociales y culturales que devienen de las sociabilidades tradicionales:

[El régimen porfirista] era una dictadura moderada que no se sostenía por la fuerza. En su madurez, hacia uso reducido de los medios de coacción, por lo demás muy restringidos [...] Fue el Porfiriato un régimen extraño: sus contemporáneos lo calificaban de patriarcal; los revolucionarios le llamaron dictadura; nuestros contemporáneos lo designan con etiquetas diferentes que van de caudillismo a régimen autoritario ${ }^{34}$.

Las afirmaciones de Guerra nos acercan a una representación del poder que no debe extrañarnos en la América Latina; la del caudillo que deviene en dictador; es el henchido del poder que apunta Balandier ${ }^{35}$, pero que se distancia de un Rosas, Santa Anna, Rodríguez de Francia y Estrada Cabrera.

Rabasa y Cosío Villegas plasmaron un perfil del régimen que se encuentra lejos del descrito en la "leyenda negra" del Porfiriato: donde el tirano no sólo era el dueño de vidas y almas, sino que ahogaba en sangre todo intento de rebeldía ${ }^{36}$. Los argumentos sostenidos por Sierra, Rabasa y Cosío Villegas exponen una visión del Porfiriato que induce a Guerra, algunos años después, a percibirlo como un régimen extraño. Aunque como se desprende de las visiones apologéticas de Sierra y de Rabasa, para algunos contemporáneos el régimen no debió resultar tan extraño, por cuanto cuadraba con la idea positiva del progreso continuo. Otra cosa parecería el régimen

Guerra. Del Antiguo Régimen... Tomo I, 1988, pp. 21-22.

35 Balandier. El poder en escenas. 1992, p. 22.

36 Véase esta "leyenda negra" exacerbada en: Turner. México bárbaro, 1992. 
a la luz del triunfo de la revolución, pues la instalación del régimen revolucionario daba por descontado que el tirano [Díaz] había sido depuesto por las restricciones impuestas a las libertades políticas y por los abusos del poder que hoy sus estudiosos señalan que ejerció con moderación, pues, contraviniendo a sus detractores, no se sostenía por la fuerza $y$ la piedra de la discordia fue su permanencia - ad perpetum - en el poder. Sin embargo, la principal fuente de extrañeza quizá se encuentre en todos esos lustros transcurridos en que los diferentes sectores sociales se resistieron a organizarse políticamente para fiscalizar, limitar y ofrecer un contrapeso al "poder absoluto" que emanaba de la autoridad central. Esta situación fue reforzada por la costumbre $y$ por un aparato electoral corruptible que sentó a Díaz en la silla presidencial merced a su antojo, siempre cuidándose de las formas, o sea, con visos de legitimidad. Esta situación no se le puede atribuir sólo a los designios de la opinión pública, como Rabasa hubiera querido. Para que el engranaje funcionase, tan bien lubricado como explica dicho autor, debió mediar algún tipo de coacción difícil de indagar en las fuentes; ya sea por omisión, ya por encubrimiento. En estas circunstancias los designios del caudillo sí son ilimitados. Las características que enunciamos podrían resultar típicas de un régimen extraño no sólo para los estudiosos del Porfiriato, sino para quienes hayan estudiado cualquier régimen de facto. De aquí el interés de Rabasa por deslindar a Díaz de regímenes como el de Santa Anna, Rosas y Rodríguez de Francia, porque a estos sí se les podía imputar el epíteto de dictadores.

Distintos autores coinciden en sus apreciaciones acerca del Porfiriato. Guerra señala que hacia 1880:

Se puede decir del sistema político porfirista que es una pirámide de vínculos y solidaridades antiguas de diferentes tipos, cuya cúspide está ocupada por el presidente. El gran logro de Porfirio Díaz es haber unificado en torno a su persona la multiplicidad de cadenas de fidelidades ya existentes y de haber hecho de ellas la armazón de todo el sistema político ${ }^{37}$.

Los caudillos, tradicionalmente poderosos, son sometidos a esta lógica y debieron probar su fidelidad al caudillo principal: "Díaz aplicó la misma política de conciliación que había aplicado a la sociedad, con mayor razón aun, a los caudillos sometidos y les garantizó los beneficios de la prosperidad económica que trajo la pacificación"38.

Atendiendo a que el extenso régimen de Díaz no debe mirarse como una estructura monolítica, sino que más bien tuvo sus propios ritmos de progreso, legitimidad $y$ crecimiento económico, podríamos concordar con Tenorio en que

[...] El Porfiriato constituye el primer periodo de relativa paz social, estabilidad política y dinámico desarrollo económico desde el fin de la guerra de Independencia. En estos años se arraiga la noción de "nación moderna": un territorio bien definido e integrado, una cultura cosmopolita, salubridad $y$ homogeneidad racial que cuadraba con las nociones occidentales de supremacía de la raza blanca ${ }^{39}$.

El gobierno porfirista utiliza distintas fuentes de legitimidad que permiten su reforzamiento y en este sentido la "ficción democrática" sustituía de hecho lo que se le negaba al cuerpo electoral por derecho: La "ficción democrática" —elección de segundo grado y apoyo unánime al caudillo en las mesas electoraleses necesaria, no solamente como fundamento irremplazable de la legitimidad del régimen, sino también como señal que va a mostrar a todos la coherencia y la fuerza del sistema político. Guerra afirma que

Guerra. México: Del Antiguo Régimen..., Tomo I, 1988, p. 236.

38 Guerra. México: Del Antiguo Régimen..., Tomo I, 1988, p. 236. Tenorio.Artilugio..., 1998, p. 10 y p.16. 
... Díaz puede ser calificado como dictador más por su permanencia indefinida en el poder que por los excesos de un poder que ejerció con moderación. La función presidencial, cualesquiera que hayan sido las discusiones eruditas de las elites, tenía ya un prestigio inmenso antes de él y lo seguirá teniendo todavía después; un prestigio inmenso para la gran mayoría de la población, que veía en ella más a una autoridad suprema de tipo antiguo, una continuación del rey de España, que al presidente de una república con poderes limitados. La imagen de la autoridad real, lejana y protectora, sobrevivió indudablemente largo tiempo después de la Independencia ${ }^{40}$.

En la búsqueda de legitimidad el régimen no escatimó esfuerzos. El sometimiento de las gavillas, la pacificación del país, la participación en eventos internacionales, el saneamiento del erario, la multiplicación en miles de kilómetros de las vía férreas impulsados por el régimen miran hacia el exterior:

La participación de México en la Exposición Mundial de París, en 1889, expone los objetivos de la nación moderna: mostrar el progreso del país y cambiar la impresión generalizada de México como un país violento, incivilizado, inseguro y salvaje. A cambio, había que presentar la imagen de México como "la tierra prometida". Para producir esta imagen la elite porfiriana se empeñó en presentar en forma impactante los recursos tanto económicos como humanos de la nación para ponerlos a la vista de todo el mundo [...] la participación de México en las ferias mundiales iba a la par de la consolidación política y económica de la elite porfiriana [...] Al participar en las exposiciones mundiales, las elites mexicanas aprendieron las verdades universales que a su vez les facilitaron consolidar su integridad $y$ poder nacional y su posición internacional ${ }^{41}$.

Fue esta elite liberal la que logró imponer su proyecto de nación y gozaría de los frutos de la paz y de la prosperidad porfiriana. No fue este un acto espontáneo ni revistió sus principales características desde los inicios del régimen, pues en efecto

[...] la paz significaba una reconciliación política y económica tras décadas de inquietud política y caos económico. Una vez alcanzada, empero, la paz también constituyó el primer consenso político real después de la independencia; mantenerla y protegerla se volvió un objetivo colectivo [...] la paz fue, sobre todo, la condición sine qua non del progreso económico ${ }^{42}$.

Después de instaurada la paz vendría el progreso económico y la reconciliación de las facciones políticas y sociales en pugna: "dueña innegable del poder bajo Díaz la elite liberal [...] una vez logrado el orden [manu militari mediante], el progreso se convierte en la palabra clave del régimen" 43 . El progreso vendría aparejado a la consolidación del régimen y este se hizo aun más evidente después de 1884, pues la segunda elección constitucional de Díaz, apunta Coatsworth,

Coincide con un nuevo equilibrio político. En todos los lugares del país, los liberales pactaron la paz con sus antiguos enemigos y en muchas regiones el apoyo de antiguos conservadores - algunos

Tenorio. Artilugio..., 1998, pp. 10-11.

42 Tenorio. Artilugio..., 1998, p. 56.

43 Guerra. México: Del Antiguo Régimen..., Tomo I. 1988, p. 302. Tenorio señala que: "La tecnología y el progreso hicieron posible apreciar el tiempo presente como el mejor de los mundos posibles (...) La comprensión del presente, a su vez, se componía de una recapitulación específica del pasado y de excepcionales anticipos del futuro". Tenorio. Artilugio..., 1998, p. 18. 
habrían servido al segundo imperiofue importante en los encuentros que sostuvieron las distintas facciones del grupo liberal en pugna. Estos pasos que se dieron hacia la conciliación nacional eran parte del esfuerzo y compromiso del régimen de Díaz que apostaba por la pacificación y por la incursión de una inversión extranjera diversificada y ayuna de temores. Fue en este sentido que el compromiso asumido por el gobierno porfirista hizo posible a las fuerzas políticas enterrar sus diferencias, y el capital extranjero representó la promesa de beneficios para ambos lados, promesa que había faltado siempre en el proceso político mexicano ${ }^{44}$.

Es en estas transacciones y negociaciones que se descubre la habilidad política de Díaz al saber imponer su voluntad $y$ arbitrar las diferencias entre grupos tradicionalmente enfrentados y recelosos de la cercanía que procuraban las distintas facciones con la autoridad central. A partir de entonces y zanjadas las diferencias, como bien lo apunta Tenorio: "el progreso fue una disparatada amalgama de esperanzas colectivas de la elite, cambios industriales y sociales reales, ecos retóricos y constante adaptación mutua entre lo moderno y lo tradicional" 45 .

La "paz porfiriana" no era del todo novedosa. La tarea de asegurar la paz a cualquier precio - que ya habrían emprendido los gobiernos de Juárez y de Lerdo- se convirtió durante todo el régimen de Díaz en la agenda inmediata: "Fue una paz impuesta a las elites y un orden impuesto a la población" ${ }^{\prime 6}$. El progreso vino aparejado a este proceso. Entendamos este progreso como el que provocó la modernización del país, inspirado en los paradigmas de los países

44 Coastworth. "Los orígenes del autoritarismo...", 1975, p. 223.

Tenorio. Artilugio..., 1998, p. 50 y Guerra. México: Del Antiguo Régimen..., Tomo I, 1988, pp. 126245.

Guerra. México: Del Antiguo Régimen..., Tomo I, 1988, p. 214 más avanzados de la época ${ }^{47}$. Con este propósito, "la elite liberal refuerza el instrumento de su poder: el Estado" 48 . Fue también competencia de la elite gobernante "la neutralización de la oposición política, el reconocimiento internacional y el logro de una relativa estabilidad económica. El México porfiriano emprendió el camino hacia la creación de una economía, sociedad e imagen nacionales modernas" ${ }^{\prime 49}$. El proceso de modernización, al menos en lo relativo a la imagen que se busca crear de México en las exposiciones mundiales, estuvo en manos de los "magos del progreso" 50. Los "magos del progreso" conocían de asuntos públicos y de finanzas y conformaban una fracción de la elite porfiriana que permanecía en constante contacto con las naciones que en ese entonces eran considerabas como el epítome de la civilización,

El tema del nacionalismo y la modernidad en el Porfiriato ha sido tratado, a través de la presencia de México en las principales exposiciones universales, por Tenorio. El autor examina la presencia de México en dichas ferias con el fin, más ambicioso, de evaluar cómo esta presencia reflejaba el concepto en formación de una nación moderna. Nacionalismo, cosmopolitismo y modernismo occidentales son aplicados al México del régimen de Díaz. Tenorio. Artilugio..., 1998, p. 9.

La necesidad de un Estado fuerte, económica y militarmente, así como el pesado clima nacionalista hicieron que la democracia y su ambigua libertad inherente se volvieran componentes valiosos pero prescindibles del modelo de nación moderna “[...] en México, la libertad como virtud política no era otra cosa que la paz [...] La paz, sin embargo, era el mayor logro de México, como también la suprema libertad alcanzada: estar libre de la violencia y la incertidumbre". Tenorio. Artilugio..., 1998, p. 17-18.

Tenorio. Artilugio..., 1998, p. 51. Ténganse como base para las características de esta elite los resultados de la investigación de Guerra. Guerra. México: Del Antiguo Régimen..., Tomo I, 1998.

Tenorio. Artilugio..., 1998, pp. 80-102. Los magos del progreso se han decantado de la elite porfiriana y se han especializado en la participación de México en las exposiciones mundiales. Para la Exposición Mundial de París 1889, los magos del progreso ya tendrían una amplia experiencia en estos menesteres. 
los llamados "científicos" son quizá el ejemplo más acabado ${ }^{51}$.

\section{EL TRIUNFO DE LA "LEGITIMIDAD” PORFIRISTA}

El enfrentamiento entre liberales y conservadores impidió que sus proyectos de Estado se consolidaran. A los liberales los aniquiló el derrumbamiento del comercio exterior $y$ de la minería y la debilidad de los proyectos conservadores devino de una profunda crisis en la agricultura. Muchos años después del más cruento enfrentamiento entre ambas facciones, en 1904, y con la perspectiva que sólo concede el tiempo, Bulnes señalaría que: "El partido liberal sufrió numerosas derrotas $y$, no obstante ellas, vivía, luchaba y crecía. El partido conservador fue vencido no obstante haber alcanzado numerosas victorias [...]"52. De allí que aun el "triunfo grande" de 1867 no resultase ante los contemporáneos como el definitivo. Juárez, Lerdo y Comonfort lograban a las justas un consenso que les permitió gobernar, pero con Díaz podemos trazar por vez primera un proyecto nacional fundado en la conciliación y en la integración ${ }^{53}$.

En todo este periodo la ausencia más evidente es la de una autoridad central fuerte capaz de consolidar un proyecto de Estado. En la base de esta situación estaban "los altos niveles de descontento social y político que provocó la distracción de recursos hacia gastos

Huelga citar a Inglaterra, Francia, Alemania y posteriormente a los Estados Unidos de América. Dentro de la plétora que constituía este círculo de eminentes porfirianos destacan Justo Sierra, José Yves Limantour, Joaquín Casasús y Francisco Bulnes. Para conocer los planteamientos del programa científico véase Hale. La transformación del liberalismo en México a fines del siglo XIX. México: Vuelta. 1991, pp. 196-207.

52 Bulnes citado por Guerra. México del Antiguo Régimen... Tomo I, 1988, p. 209.

53 Esta es una de las principales tesis desarrolladas por Jiménez Marce en: Jiménez. "La creación..., 2002 . militares" 54 , situación que no pretende obviar el descontento que despertaba la arbitrariedad que prevalecía en el trato a los disidentes y críticos del régimen. Al principio se utilizó el gasto militar para hacer frente a las guerras intestinas y luego para enfrentar las intervenciones extranjeras. El Porfiriato, como lo apuntó Cosío Villegas, es indivisible de la república restaurada. Esta indivisibilidad apunta a valorar una continuidad entre ambos periodos. El saldo fue favorable por cuanto su remanente fue un verdadero proyecto de nación que llenó las expectativas de los mexicanos hasta 1910. Resaltamos que entre 1867 y 1910 han transcurrido más de 40 años que casi igualan, en proporción numérica, a los años de la anarquía y de la ausencia de un proyecto nacional viable. Situación que insistimos, imperó, entre 1810 y 1867.

Señala Coastworth que todo apuntaba a hacer evidente la necesidad de un "consenso político al nivel nacional" y este no se logró sino hasta la restauración de la República en $1867^{55}$. Acerca de la significación historiográfica de la república restaurada existe el consenso de que esta precedió y allanó el camino al Porfiriato. Este argumento se ha constituido en un lugar común entre la historiografía que se ocupa de este periodo, aunque también cabe aquella historiografía que exalta la restauración de la República y otea al Porfiriato, según lo establecido por la ortodoxia revolucionaria. Cosío Villegas, Bazant, Guerra y Katz han sido precursores en la dimensión histórica que se le ha otorgado a dicha restauración en el entendido de que precedió y preparó al Porfiriato. Más recientemente, Erika Pani ha afirmado que:

Dentro de la reconstrucción histórica del siglo XIX mexicano, surge 1867 como fecha mágica, como parteaguas definitivo. El triunfo de la república sobre el ejército de Maximiliano significó

Coastworth. "Los orígenes del autoritarismo..." 1975, p. 213.

55 Coastworth. "Los orígenes del autoritarismo..." 1975, p. 214. 
la victoria de la nación soberana sobre las huestes invasoras del imperio más poderoso del mundo; la nulificación del anacrónico proyecto político conservador y la consolidación del Estado moderno, liberal y republicano ${ }^{56}$.

Entre la restauración de la República y el ascenso de Díaz al poder el enfrentamiento se traslada al seno de las distintas facciones del liberalismo. Los conservadores, ante la flagrante derrota del ejército francés y sus colaboradores, quedan aniquilados políticamente. La conciliación nacional después de 1867 apunta a evitar el enfrentamiento entre los principales líderes liberales: Lerdo de Tejada, Benito Juárez y Porfirio Díaz. Pero la confrontación por el poder de todos modos se dio $^{57}$. Cada caudillo durante la república restaurada, apoyado en su pirámide de fidelidades, está convencido de la legitimidad de una insurrección de ese pueblo cuya representación ha asumido en las guerras libradas por la Constitución y por la nación ${ }^{58}$.

56 Pani. Para mexicanizar el Segundo Imperio..., 2001, p. 15.

La llegada al poder de Porfirio Díaz en 1876 es la victoria de una coalición de caudillos regionales en contra del presidente Lerdo de Tejada. Durante su primera presidencia, de 1876 a 1880, Díaz, a pesar de todo su prestigio, sigue siendo todavía primus inter pares, $y$ reconoce a sus amigos y a sus fieles la posesión de sus "feudos regionales". Es cierto que aquellos personajes que pudieran representar una amenaza para el poder de Díaz, o que se mostrara poco dócil a sus sugerencias, no podía seguir en el poder en su Estado. Pero también es cierto que el gobierno central interviene muy poco o nada en los asuntos interiores del Estado cuando la lealtad política está asegurada. Guerra. México: Del Antiguo. Tomo I, 1988, p. 49. Díaz se reservaba la designación de los diputados y senadores; es decir, el control de la "representación nacional". Los otros cargos siguen siendo elegidos libremente por el poder regional. Guerra. México. Del Antiguo... Tomo I, 1988, p. 51. Así se constituyó un sano equilibrio entre el poder nacional y el poder regional, aunque el primero, a todas luces, debilitó el poder de los caciques regionales.

58 Guerra. México: Del Antiguo Régimen... Tomo I, 1988, p. 210 .
[No fue sino hasta que] los diferentes grupos políticos encabezados por Sebastián Lerdo de Tejada y José María Iglesias se reconciliaron e incorporaron al Partido Liberal, que la existencia de intereses comunes dio origen a una elite relativamente unida. Las antiguas oligarquías económicas poco a poco se confundieron con los nuevos grupos económicos y políticos. El tono que esta elite dio a la vida urbana creó en el imaginario la impresión de una belle époque mexicana ${ }^{59}$.

La reconciliación, de hecho, significa haber alcanzado un equilibrio político interno tras la derrota de los liberales lerdistas. Aunque el gobierno de Díaz no superó lo que algunos han llamado la atomización política y económica, sí instituyó una autoridad central que se basaba, sobre todo, en sólidos intereses comunes. Era un equilibrio fundamentado en la conveniencia mutua de la elite, y sus solidarités, ya fuesen modernas o tradicionales, se enraizaban en el pragmatismo inherente al ejercicio del poder 60 .

La toma del poder por Porfirio Díaz realizaba una vez más la transferencia simbólica de la soberanía del "pueblo". La soberanía de los caudillos liberales múltiples con sus "voluntades nacionales", en acecho, pasaba al caudillo liberal, unificador de la élite ${ }^{61}$. Esta matriz se repite, para la misma época por toda América Latina. Fue la primera elección constitucional de Díaz la que procuró el apaciguamiento y el despojo del poder de antiguos caciques locales.

59 Tenorio. Artilugio..., 1998, p. 51.

60 Guerra. México: Del Antiguo Régimen..., Tomo I, 1988, pp. 126-181.

61 Guerra. México: Del Antiguo Régimen...Tomo I, 1988 , p. 210. En la misma época y por transacciones en el seno de la oligarquía Costa Rica se encuentra ante los estertores de su penúltima dictadura. El dictador Tomas Guardia Gutiérrez (1870-1882) muere en pleno cargo de sus funciones vitalicias en 1882 . No habrá otra dictadura sino hasta la de Tinoco (1917-1919). Es, también, el caso de la Guatemala de Justo Rufino Barrios. 
De este modo fortaleció la asunción de un poder central e indiscutible.

\section{LA REHABILITACIÓN HISTÓRICA DEL PORFIRIATO}

El Porfiriato en la versión siniestra divulgada por sus detractores fue el expediente al cual se recurrió al triunfar la Revolución de 1910. Los ideólogos revolucionarios, en su ortodoxia, negaron al Porfiriato sus raíces históricas y su responsabilidad en la modernización de México. Esta situación sufre un cambio en la década de 1950, pero en especial después de 1970. Los críticos al argumento de la "revolución continua", encontrarán en el régimen de Díaz y en sus críticos la principal fuente contrargumental para demostrar que la revolución de 1910 se ha agotado a tal nivel que el mito de la "revolución continua" es un ardid de quienes han usufructuado el poder desde entonces. El otrora monolítico PRI será el blanco de estas críticas.

Estudiosos mexicanos y extranjeros de sobrado prestigio intelectual señalan un nuevo camino para los estudios porfirianos. Con esta propuesta de interpretación hemos iluminado el sendero que han transitado algunos estudios sobre el Porfiriato y rotura, además, nuevos campos de conocimiento. Al hacer tabla rasa del pasado se sacrificaba lo que de significativo tenía el Porfiriato como periodo histórico. Cualquier periodo histórico en el que las omisiones sean de mayor alcance que el proceso mismo de la historia, condena a nuestra profesión a las manipulaciones del poder descarnado y a una responsabilidad compartida en los cuadros más atroces que ha padecido la América Latina. ¿Es este el caso del México porfiriano? Algunos estudiosos especularán acerca de que los primeros años revolucionarios retardaron el crecimiento económico y la reforma que se encontraba en ciernes en el México de Díaz. Cuando México está a punto de ingresar en el "concierto de las naciones" los miembros de la elite porfiriana se preocuparon por mostrar los avances en los campos científico, académico, comercial y cultural ${ }^{62}$.
Esta necesidad de mostrarse al mundo como el epítome de la modernidad en América Latina condujo, por otro lado, a la explosión social de 1910. El discurso de la "paz porfiriana" se hacía añicos ante el peso de los acontecimientos.

La instauración de la paz condujo al orden y al progreso, a la integración y a la conciliación nacional:

La voluntad de la paz a toda costa que se manifiesta en la sociedad y la aceptación de la realidad social $-y$ por lo tanto de la Iglesia- por el caudillo, dan a este una base social muy fuerte. Esta base está reforzada porque el caudillo ha sabido integrar de hecho en el funcionamiento de su régimen los valores y los vínculos de las sociabilidades antiguas. La adhesión de la elite y el alivio social van a crear una "voluntad nacional" muy fuerte, un consenso del que se vale el presidente para mantenerse en el poder ${ }^{63}$.

La paz, la conciliación, la búsqueda de legitimidad, el anhelo de instaurar una "voluntad nacional" y el terreno apropiado para que realizara sus negocios la elite porfirista condujeron a una amplia aceptación del régimen que no mostró grandes fisuras sino hasta la llegada del siglo $\mathrm{xx}^{64}$.

62 Con alguna ironía Tenorio describe el desvelo que tuvo Vicente Riva Palacio en mostrar que la "raza indígena" era más evolucionada por la ausencia de un molar.

Guerra. México: del Antiguo Régimen..., Tomo I, 1988, p. 211.

La "Conferencia Creelman" es quizá el documento más importante para advertirnos sobre las fisuras del régimen. La sucesión presidencial en 1910 de Francisco Madero con todo el programa del Partido Antirreleccionista es, también, un documento que nos acerca a la realidad política que se vivió en los últimos años del Porfiriato. Guerra advierte que "en la última década del Porfiriato afloraron las tensiones causadas por la modernización capitalista, ya que el régimen carecía de políticas económicas y sociales con la flexibilidad 
El régimen había instalado confortablemente a una elite en el poder y los sectores sociales excluidos empiezan a pugnar por su participación. Los sectores medios no tardan en organizarse a nivel partidista $y$ a desafiar al poder establecido. El aval a la nueva situación vino de donde menos se hubiera esperado: el anciano dictador se descubre emitiendo criterio al favorecer la formación de partidos políticos en la Conferencia Creelman (1908). Dicha conferencia creó la plataforma política para la formalización de ciertas libertades públicas a las que los mexicanos no tenían acceso por una acción deliberada del régimen que temía la asunción de una oposición sistemática. Esta situación aunada a la participación de una opinión pública más amplia y más crítica que la porfiriana tradicional desencadenó las tensiones que devinieron en la Revolución. Entre la Conferencia Creelman y el brote revolucionario transcurren tan sólo 2 años.

\section{CONCLUSIÓN}

Para entender el proceso que conduce a la rehabilitación histórica del Porfiriato hemos caracterizado la articulación que vincula al régimen con la urbe capitalina, con la historiografía, con la "paz porfiriana" y con la emergencia de una "legitimidad". El imaginario colectivo mexicano, aun en nuestros días tiende a escamotear todo lo relacionado con el régimen de Díaz y no le concede siquiera el pedazo de gloria que cupo a los arquitectos mexicanos y extranjeros que se esforzaron por hacer de la ciudad de México, apenas se iniciaba el siglo XX, una vitrina de cara a la modernidad. Para los críticos el eclecticismo arquitectónico que habría privado al final del régimen era un síntoma de debilidad y se interpretaba como un romanticismo residual.

necesaria para tomar el control del proceso. Para dar cohesión al Estado, Díaz no hizo más que retoques progresivos en la Constitución de 1857: estas modificaciones llevaron a un aumento de las competencias del gobierno central en materia económica". Guerra, México: del Antiguo..., Tomo I, 1988, p. 50.
El proceso histórico que hemos analizado explica la centralización del poder en manos del gobierno nacional y el debilitamiento de la participación política que habría caracterizado al México posterior a la Independencia ${ }^{65}$. Esta matriz, que en la época de Díaz se presentaba al público como ideal, se convirtió pronto en el detonante de la Revolución. El sistema político se tornó vulnerable y puso en evidencia que los beneficios de la modernización se concentraron en una pequeña elite empresarial, inversionista y latifundista insolentemente rica. La contrapartida eran esos amplísimos contingentes de indígenas pobres, analfabetas $y$ despojados de sus tierras y los léperos de las ciudades. La situación descrita desnuda las raíces del descontento social que en los últimos años del régimen condujeron inexorablemente al triunfo de la Revolución. En el transcurso del siglo xx la situación no cambió visiblemente, al menos en cuanto a la incorporación de los sectores que quedaban al margen del desarrollo social, menos aun cuando apenas inaugurado el tercer milenio se anuncia con gran algarabía que el mexicano Carlos Slim es el hombre más rico del planeta. ¿Habrá cambiado la suerte de casi dos terceras partes de los mexicanos? La evidencia demuestra todo lo contrario; el índice de pobreza extrema y los niveles de inequidad social son de los más altos de la América Latina. Otros problemas sociales como la lucha a muerte entre los carteles de la droga y la inmigración masiva a un país huésped con una política migratoria leonina asolan a la sociedad mexicana. Quienes establecieron un parangón entre el Porfiriato y los regímenes revolucionarios que le sucedieron no se equivocaron. Cosío Villegas fue el primero en señalar esta continuidad. ¿Fue Díaz un hombre probo? La rehabilitación del régimen va más allá porque mucho han escrito los apologistas a favor de Díaz y caudales de tinta han derramado sus detractores. La probidad que algunos le señalan a Díaz ha sido más difícil de encarar por los Salinas de Gortari, o bien, por Coastworth. "Los orígenes del autoritarismo...", 1975, p. 223. 
las circunstancias que rodearon al asesinato de Colosio. Ambas situaciones se han interiorizado en la cultura política de los mexicanos. Porfirio Díaz sigue acumulando indulgencias históricas. Al final del sexenio de Salinas de Gortari hubo una iniciativa que procuraba repatriar los restos del dictador, que hasta el día de hoy reposan en el parisino cementerio de Montparnasse.

No ha sido mi intención exculpar al régimen de sus dimensiones funestas, pero el centrarme en la inmensa modernización que sufren las distintas estructuras mexicanas bajo el régimen de Díaz indica que, lejos de distanciarme del periodo en cuestión, pongo especial énfasis en el arribo de México al concierto de las naciones que se tenían por "civilizadas" para la época de la celebración del primer centenario de la Independencia de México en 1910.

\section{BIBLIOGRAFÍA}

FUENTES PRIMARIAS IMPRESAS

Gortari Rabiela, Hira de. Memoria y encuentros: la ciudad de México y el distrito federal (1824-1928), 3. México: Instituto Mora, 1988.

Memoria de los trabajos emprendidos y llevados a cabo por la Comisión Nacional del Centenario de la Independencia designada por el Presidente de la República el $1^{\circ}$ de abril de 1907. México: Imprenta del Gobierno Federal, 1910.

García, Genaro. Crónica oficial de las fiestas del Primer Centenario de la Independencia de México. México: Centro de Estudios de Historia de México Condumex. Chimalistac. 1991.

\section{FUENTES SECUNDARIAS}

Acevedo, Esther. "Las imágenes de la Historia (1863-1867). Memoria y destrucción".
Memoria del Museo Nacional de Arte 3. 1991.

.El legado artístico de un imperio efímero. Maximiliano en México, 18641867". Testimonios artísticos de un episodio fugaz (1864-1867). México: Museo Nacional de Arte, 1995-1996.

Agostoni, Claudia y Speckman, Elisa. Modernidad, tradición y alteridad. La ciudad de México en el cambio de siglo $(X I X-X X)$. México: Universidad Nacional Autónoma de México. Instituto de Investigaciones Históricas, 2001.

Annino, Antonio. "Ciudadanía "versus" gobernabilidad republicana en México. Los orígenes de un dilema”. Sabato, Hilda (Coord.), 1999.

Baczko, Bronislaw. Los imaginarios sociales. Memorias y esperanzas colectivas. Buenos Aires: Ediciones Nueva Visión, 1991.

Balandier, Georges. El poder en escenas. De la representación del poder al poder de la representación. Barcelona: Ediciones Paidós Ibérica, 1992.

Beezley, William H., et ál. Rituals of Rule, Rituals of Resistence. Public Celebrations and Popular Culture in Mexico. Wilmington: Scholarly Resources, 1994. et ál. ¡Viva México! ¡Viva la independencia! Celebrations of September 16. Wilmington, DE: Scholarly Resources Inc., 2001.

Bulnes, Francisco. La guerra de Independencia. Hidalgo-Iturbide. México: Ediciones El Caballito. Universidad Iberoamericana, 1992. 
Las grandes mentiras de la historia. México: Dirección General de Publicaciones del Consejo Nacional para la Cultura y las Artes, 1991.

Coatsworth, John H. "Los orígenes del autoritarismo moderno en México". Foro Internacional. Revista Trimestral XVI. 2, oct.-dic. Publicada por El Colegio de México, 1975.

Connolly, Priscilla. El contratista de don Porfirio. Obras públicas, deuda y desarrollo desigual. México: El Colegio de Michoacán/Universidad Autónoma Metropolitana Azcapozalco/Fondo de Cultura Económica, 1997.

Cosío Villegas, Daniel. "La República Restaurada. La vida social". Historia Moderna de México, t. III. México: Editorial Hermes, 1956.

. "El Porfiriato. La vida social". Historia Moderna de México, t. IV. México: Editorial Hermes, 1957.

"El Porfiriato. La vida política interior". (Parte segunda). Historia Moderna de México, t. x. México: Editorial Hermes, 1972.

Llamadas. México: El Colegio de México, 1980.

Fernández, Justino. El arte moderno en México. México: Antigua Librería Robredo, José Porrúa e hijos, 1937.

El arte del siglo XIX en México. México: Universidad Nacional Autónoma de México, 1983.

Arte mexicano. De sus orígenes a nuestros días. México: Editorial Porrúa, 1968.
Florescano, Enrique. Historia de las historias de la nación mexicana. México: Taurus, 2002.

"La memoria de la consumación de la Independencia, 1821". Mimeografiado, 1992.

. La bandera mexicana. Breve historia de su formación y simbolismo. México: Fondo de Cultura Económica, 1995.

- Memoria mexicana. México: Fondo de Cultura Económica, 1994.

- "Patria y nación en la época de Porfirio Díaz”. Signos Históricos 13. Revista semestral, enero-junio. México: Departamento de Filosofía CSH/UAM/ Iztapalapa, 2005.

. Imágenes de la Patria a través de los siglos. México: Taurus, 2005.

García Cubas, Antonio. Geografía e historia del Distrito Federal. México: Instituto de Investigaciones Dr. José María Luis Mora, 2004.

Garner, Paul. Porfirio Díaz: del héroe al dictador. Una biografía politica. México: Editorial Planeta Mexicana, 2003.

Ginzburg, Carlo. Mitos, emblemas e indicios. Barcelona: Gedisa Editorial, 1989.

Guerra, François-Xavier. México del Antiguo Régimen a la Revolución. ts., I y II. México: Fondo de Cultura Económica, 1988.

Guerra, François-Xavier y Lempérière et ál. Los espacios públicos en Iberoamérica. Ambigüedades y problemas. Siglos 
XVIII-XIX. México: Fondo de Cultura Económica y Centro Francés de Estudios Mexicanos y Centroamericanos, 1998.

. Modernidad e independencias. Ensayos sobre las revoluciones hispánicas. México: Editorial Mapfre y Fondo de Cultura Económica, 1997.

Guerrero Zorrilla, Rubén. "Un símbolo llamado Juárez". Historia y Grafía 13. México: Universidad Iberoamericana, 1999.

"El renacer de la historia política: razones y propuestas". Historias 54, Revista de la Dirección de Estudios Históricos del Instituto Nacional de Antropología e Historia. México DF, 2003.

Hale, Charles. La transformación del liberalismo en México a fines del siglo XIX. México: Vuelta, 1991.

Hernández Franyuti, Regina. (comp.). La Ciudad de México en la primera mitad del siglo XIX. Tomos I y II. México: Instituto de Investigaciones José María Luis Mora, 1994.

Instituto Nacional de Bellas Artes. La construcción del Palacio de Bellas Artes. México: Instituto Nacional de Bellas Artes en coedición con Siglo XXI Editores, 1994.

Jiménez Marce, Rogelio. "La creación de una genealogía liberal". Historias 51, eneroabril. Revista de la Dirección de Estudios Históricos de Antropología e Historia. México DF, 2002.

Johns, Michael. The City of Mexico in the Age of Diaz. University of Texas Press, 1997.

Katzman, Israel. La arquitectura contemporánea mexicana. Precedentes y desarrollo. México: Instituto Nacional de Antropología e Historia, 1963.
- Arquitectura del siglo XIX en México. México: Centro de Investigaciones Arquitectónicas. Universidad Autónoma de México, 1973.

Kennedy, Emmet. A Cultural History of the French Revolution. Yale University Press, 1989.

Knight, Alan. La Revolución Mexicana 2. México: Grijalbo, 1996.

Lempériére, Annick. "Los dos centenarios de la independencia mexicana (1910-1921): de la historia patria a la antropología cultural". Historia Mexicana xLV, oct.-dic. 1995.

Lynch, John. Las revoluciones hispanoamericanas 1808-1826. Barcelona: Editorial Ariel SA, 1983.

Madero, Francisco I. La sucesión presidencial en 1910. México.

Manrique, Jorge Alberto. "Historia de las Artes Plásticas”. Historia Mexicana, 1965-1966, $\mathrm{XV}$, oct.-marzo.

"Arte, modernidad y nacionalismo (1867-1876)". Historia Mexicana XVII. 2, oct.-dic. 1967.

Mariscal, Nicolás. "El desarrollo de la arquitectura en México". S/l. s/e, 1901.

Maza, Francisco de la. Obras escogidas. México: Instituto de Investigaciones Estéticas, 1992.

Miranda Pacheco, Sergio. "Problemática urbana y reforma político administrativa en el Distrito Federal, 1903-1914". Miradas recurrentes $I$. La ciudad de México en los siglos XIX y XX. María del Carmen Collado (coordinadora). México: Instituto Mora. Universidad Autónoma Metropolitana, Unidad Azcapozalco, 
División de Ciencias Sociales y Humanidades, 2004.

Moreno Toscano, Alejandra. "México". R. Morse, (comp.). Las ciudades latinoamericanas 2. Desarrollo histórico. México: SEP, Colección Sepsetentas, 97, 1973.

Museo Nacional de Arte. Testimonios artísticos de un episodio fugaz (1864-1867.) México: Instituto Nacional de Bellas Artes, 1995-1996.

Navarrete, Federico y Oliver, Guilhem, coord. El héroe entre el mito y la historia. México: Universidad Nacional Autónoma de México y Centro Francés de Estudios Mexicanos y Centroamericanos, 2000.

Noelle, Louise y Schavelzon, Daniel. "Monumento efímero a los héroes de la independencia (1910)". Anales del Instituto de Investigaciones Estéticas 55. México: UNAM, 1986.

Nora, Pierre. "De l'archive a l'embleme. L'ére de la commémoration". Les lieux de mémoire. La Nation. Paris: Gallimard, 1992.

Novo, Salvador. México, imagen de una ciudad. México: Fondo de Cultura Económica, 1967.

Los paseos de la ciudad de México. México: Fondo de Cultura Económica, 1980.

O'Gorman, Edmundo. "Hidalgo en la Historia". Discurso de ingreso pronunciado por el señor D. Edmundo O'Gorman. Memorias de la Academia Mexicana de la Historia. Tomo XXIII, julio-sept, 1964.

. Seis estudios históricos de tema mexicano. México: Universidad Veracruzana, 1960.
México, el trauma de su historia. México: UnAM, 1977.

Ortiz Monasterio, José. México eternamente. Vicente Riva Palacio ante la escritura de la historia. México: Instituto de Investigaciones Dr. José María Luis Mora/ Fondo de Cultura Económica, 2004.

Pani, Erika. "Para nacionalizar el Segundo Imperio. El imaginario político de los imperialistas". [Tesis para obtener el título de Doctor en Historia]. El Colegio de México. Centro de Estudios Históricos, 1998.

Para mexicanizar el Segundo Imperio. El imaginario político de los imperilistas. México: El Colegio de México/Instituto de Investigaciones Dr. José María Luis Mora, 2001.

. El Segundo Imperio. Pasados de usos múltiples. México: Centro de Investigación y Docencia Económica/ Fondo de Cultura Económica, 2004.

Panofsky, Edwin. Estudios sobre iconología. Madrid: Alianza Editorial, 1992.

Piña Dreinhofer, Agustín. "Arquitectura neoclásica”. Serie Las Artes de México. México: Universidad Nacional Autónoma de México. Dirección General de Difusión Cultural. Departamento de Humanidades, s/f.

"Siglo XIX: Arquitectura porfirista". Serie Las Artes de México. Universidad Nacional Autónoma de México. Dirección General de Difusión Cultural. Departamento de Humanidades, s/f.

Rabasa, Emilio. La evolución histórica de México. Sus problemas sociológicos. México: Ediciones Frente Cultural, 1920. 
La evolución histórica de México. México: UnAm y Grupo Editorial Miguel Ángel Porrúa, 1986.

Rama, Ángel. La ciudad letrada. Hannover: Ediciones del Norte, 1984.

Reese, Thomas F. and McMichael Reese, Carol. "Revolutionary Urban Legacies: Porfirio Díaz's Celebrations of the Centennial of Mexican Independence in 1910". Arte, historia e identidad en América. Visiones comparativas. Tomo II. México. XVII Coloquio Internacional de Historia del Arte. Instituto de Investigaciones Estéticas de la Universidad Autónoma de México, 1994.

Reyes Heroles, Jesús. El liberalismo mexicano. Los orígenes. Tomo I. México: Universidad Nacional Autónoma de México, 1957.

.El liberalismo mexicano. La sociedad fluctuante. Tomo II. México: Universidad Nacional Autónoma de México, 1958.

El liberalismo mexicano. La integración de las ideas. Tomo III. México: Universidad Autónoma de México, 1961.

Riva Palacio, Vicente. Cuentos del General (compilados por José Ortiz Monasterio). México: Coedición del Consejo Nacional para la Cultura y las Artes/Universidad Nacional Autónoma de México/Instituto Mexiquense de Cultura/Instituto de Investigaciones José María Luis Mora, 1997.

. El libro rojo. México: Consejo Nacional para la Cultura y las Artes, 1989.

Los Ceros (Galería de Contemporáneos). México: Coedición del Consejo Nacional para la Cultura y las Artes/
Universidad Nacional Autónoma de México/Instituto Mexiquense de Cultura/ Instituto de Investigaciones José María Luis Mora, 1996.

México a través de los siglos. Historia general y completa del desenvolvimiento social, político, religioso, militar, artístico, científico y literario de México desde la antigüedad más remota hasta la época actual. Tomo vi y Tomo VII. México: Editorial Cumbre, SA. 1987 y 1988.

Rodríguez Prampolini, Ida. La crítica de arte en México en el siglo XIX. Estudios y Documentos. Tomos I, II, III. México: Universidad Autónoma de México e Instituto de Investigaciones Estéticas, 1997.

Romero, José Luis. Latinoamérica: las ciudades y las ideas. México: Siglo XXI Editores, 1984.

Sabato, Hilda. Coord. Ciudadanía politica y formación de las naciones. Perspectivas históricas de América Latina. México: El Colegio de México y Fondo de Cultura Económica, 1997.

Schavelzon, Daniel (comp.). La polémica del Arte Nacional en México, 1850-1910. México: Fondo de Cultura Económica, 1988.

Sierra, Justo. Apuntes para un libro: México social y político. México DF: Secretaría de Hacienda y Crédito Público. Dirección General de Prensa, Memoria, Bibliotecas y Publicaciones, 1960.

. Evolución politica del pueblo mexicano. México: Editorial Porrúa, 1998.

- Obras Completas IV. Periodismo Político. México: Universidad Autónoma de México, 1991. 
. Obras Completas VIII. La Educación Nacional. México: Universidad Autónoma de México, 1991.

Obras Completas IX. Ensayos y textos elementales de Historia. México: Universidad Autónoma de México, 1991.

. Obras Completas Tomo XII. Evolución política del pueblo mexicano. México: Universidad Nacional Autónoma de México, 1957.

Starobinski, Jean. 1789, los emblemas de la razón. Madrid: Taurus, 1988.

Tenembaum, Barbara. "Streetwise History: The Paseo de la Reforma and the Porfirian State, 1876-1910". Beezley, W., et ál. Rituals of Rule, Rituals of Resistence. Public Celebrations and Popular Culture in Mexico. Wilmington: Scholarly Resources, 1994.

Tenorio, Mauricio. "Crafting a modern nation. Mexico: Modernity and nacionalism at World'Fairs. 1880's-1920's'. [Tesis doctoral]. University of Stanford, 1993.

. "1910 Mexico City: Space and Nation in the City of the Centenario". Journal of Latin American Studies 28. Cambridge University Press, 1996.

Artilugio de la nación moderna. México en las exposiciones universales, 1880-1930. México: Fondo de Cultura Económica, 1998.
Turner, John Kenneth. México bárbaro. México: Editores Mexicanos Unidos, 1992.

Uribe, Eloisa (coord.). Y todo... por una nación. Historia social de la producción plástica de la ciudad de México. 1761-1910. México: INAH, 1987.

Valadéz, José C. El porfirismo. Historia de un régimen. El nacimiento. México: Universidad Nacional Autónoma de México, 1977.

. El porfirismo. Historia de un régimen. El crecimiento I y II. México: Universidad Nacional Autónoma de México, 1977.

Vázquez, Josefina Zoraida. Nacionalismo y educación en México. México: El Colegio de México, 1979.

Zárate Toscano, Verónica. "El lenguaje de la memoria a través de los monumentos históricos en la ciudad de México (Siglo XIX)". Séminaire: "Cultures et sociétés de l'Amérique coloniale, Xvie-Xxe siècle", 2001.

"El Paseo de la Reforma como eje monumental". Miradas recurrentes I. La ciudad de México en los siglos XIX y XX. María del Carmen Collado (coordinadora). México: Instituto Mora, Universidad Autónoma Metropolitana, Unidad Azcapozalco, División de Ciencias Sociales y Humanidades, 2004. 
